\title{
Azolla Bacteria Promoting Rice Growth Under SalineCondition
}

\author{
Waleed Asghar ${ }^{1 *}$, Farhan Iftikhar ${ }^{2}$, Abdul Latif ${ }^{3}$ and Imran Ali Khan ${ }^{1}$ \\ ${ }^{1}$ School of Environment, China \\ ${ }^{2}$ Soil Department, Gomal University Kpk, Pakistan \\ ${ }^{3}$ School of Resources and Environment, Anhui Agricultural University,China
}

Submission: September 08, 2018, Published: October 04, 2018

"Corresponding author: Waleed Asghar, Beijing Normal University, 100875 Beijing, China; Tel: +86-13126825879;

Email: waleedasghar978@gmail.com

\begin{abstract}
Azolla as a use for nitrogen in rice crops its can be used for reclaiming the saline soil and reducing the Electro conductivity and $\mathrm{pH}$ and also provide nitrogen to plant and soil and improve soil texture and structure. It is measured with a conductivity cell or EC meter and expressed in milliohms or milli-Siemens $(\mathrm{mS})$ per $\mathrm{cm} .1 \mathrm{Mho}=1$ Siemens. The original EC of Soil is 1.3 and after induces salinity level create the EC became reach to $7 \mathrm{dSm}^{-1}$. The $\mathrm{pH}$ after the development of salinity reaches to 8.2. After the analysis of soil sample by hydrometer the soil class become occurred in clay soil texture. In initial growth of rice studied, the data show that initial growth in control was to week as compare to treatment three. In treatment two where the salinity $3 \mathrm{dSm}^{-1}+$ Azolla were show no resistance to growth but in treatment three where the salinity $7 \mathrm{dSm}^{-1}+$ Azolla were show to much resistance. In each plot five Plants were selected and measure the length of each plant from top to bottom and taken average of five plants. The length of control pot rice is $40 \mathrm{~cm}$ mean without azolla and treatment two the average height of the plants was $70 \mathrm{~cm}$ where the salinity level is $3 \mathrm{dSm}^{-1}+$ Azolla. In treatment three where the salinity $7 \mathrm{dSm}^{-1}+$ Azolla show $43 \mathrm{~cm}$ plant height.
\end{abstract}

Keywords: Azollabacteria; Saline soil; Rice; Plant growth

\section{Introduction}

In addition to the use of Azolla as an $\mathrm{N}$ source for rice crops, it can be used for reclaiming saline soils, reducing evapotranspiration, and to control weed infestations in rice crops [1]. Azolla can also be used directly as a feed for fish, and a technology called "Azobiofer" has been developed for the production and use of Azolla for irrigated rice and fish cultivation [2].It can also be used to purify wastewater as it can accumulate $\mathrm{P}$ and some heavy metals from water $[3,4]$. However, there are some constraints on the production and use of Azolla, like the availability and control of water supplies, P limitations in soils, predators of Azolla, and its temperature sensitivity. A high-temperature- tolerant Azolla species, Azollamicrophylla, can be used in tropical countries to overcome the problem of its sensitivity to high temperatures. This species can survive at temperatures of up to $38^{\circ} \mathrm{C}$ and can fix N[5]. Other problems of Azolla production can be alleviated by proper management practices.

Azolla isa free-floatingfreshwaterfern, whichfixes atmospheric $\mathrm{N}$ through the symbiotic association with Anabaena azollae that lives inside the dorsal lobes of Azolla leaves, potentially supplying a substantial amount of $\mathrm{N}$ to the rice crop [6]. Azolla can fix 22$40 \mathrm{~kg} \mathrm{~N}$ ha-1 within 30 days [7]. It can be grown simultaneously with irrigated rice without additional requirements for land and water $[8,9]$. Rice yields can be increased by $1.4-1.5 t$ ha $^{-1}$ by Azollaapplication [10]. There are now seven recognized species of the family Azollaceae: Azollacaroliniana, A. Azolla can contribute $40-60 \mathrm{~kg} \mathrm{~N} \mathrm{ha}^{-1}$ per rice crop [11]. The $\mathrm{N}$ accumulated by Azolla is derived mostly from the air. It has been established, by using the $15 \mathrm{Ntracer}$ technique, that rice plants can assimilate around 33\% of the $\mathrm{N}$ fixed by Azollawithin 60 days.

More than half of the world inhabitants is reliant onrice. The rice crop was sown on 145 million hectares of land in 1988, producing 468 million tons. About $75 \%$ of rice land are wetlands where rice grows in waterlogged fields during part or all of the cropping period. From the point of view of yield sustainability, traditional wetland rice cultivation has been extremely successful. Moderate but stable yield has been maintained for thousands of years without adverse effects on soil [12]. This isbecause flooding allows the establishment of environmental conditions that maintain soil $\mathrm{N}$ fertility. In particular, flooding leads to the differentiation of a wide range of macro- and micro-environments that differ in their redox potential, physical properties, light status, and nutrient sources for the micro flora. As a result, all groups of $\mathrm{N}$-fixing microorganisms find environments suitable for their growth in wetland rice fields (Figure 1)[13-16]. 


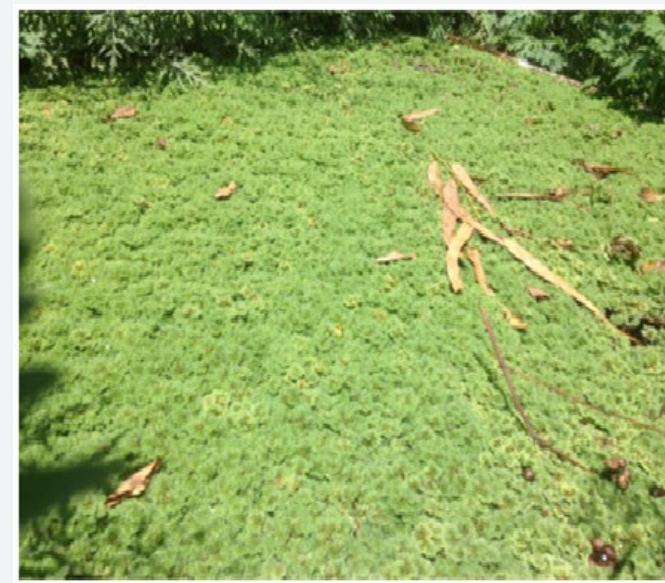

A

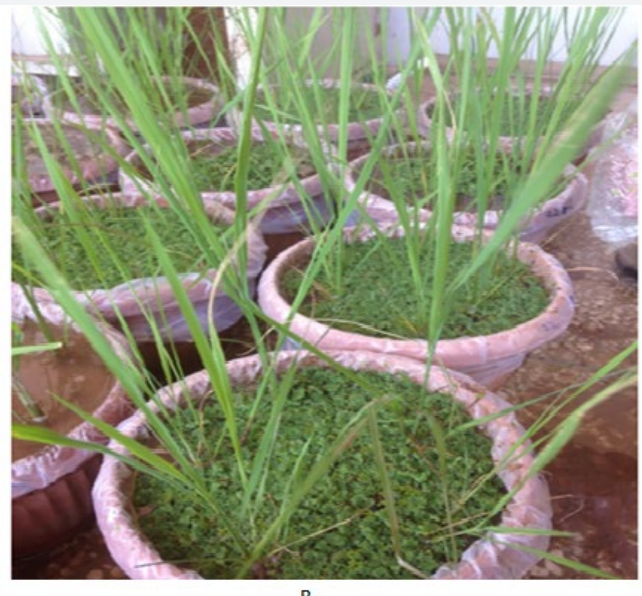

B

Figure 1: All groups of $\mathrm{N}$-fixing microorganisms find environments suitable for their growth in wetland rice fields.

\section{Material and Method}

The experimental study conducted at National Agriculture Research Center Islamabad during june-2018.The experimental study was design pots with three times repetition and two level of salinity. Each pot contains $4 \mathrm{~kg}$ soil. Azolla used as bio-fertilizer and promoter of the rice crop growth under different salinity level.Azolla apply before the rice transplanting. The following experimental parameter was study.

\section{Soil sample}

The soil sample taken from National Agriculture Research center Islamabad anddeveloped two salinity levels. The soil samples were dry and grind. After grinding the soil samplesewed and fill the pots.

\section{Electric conductive (EC)}

The $5 \mathrm{~g}$ soil sample taken in conical flask and add water up to saturation level. The soil pest place for 24 hour or overnight. The vacuum pump used to get the soil extract. The electric conductivity find from EC meter. Its unit $\mathrm{dSm}^{-1}$.

\section{pH}

The $5 \mathrm{~g}$ soil sample taken in conical flask and add water up to saturation level. The soil pest place for 24 hour or overnight. The vacuum pump used to get the soil extract. The $\mathrm{pH}$ meter electrode place in soil extracts and waits for reading.

\section{Soil texture}

The soil sample Texture Determination refers to the size of the particles that make up the soil.The terms clay, sand and silt refer to relative sizes of the soil particles.Sand, being the larger size of particles, feels gritty.Silt, being moderate in size, has a smooth or floury texture. Clay, being the smaller size of particles, feels sticky. Hydrometer were used for texture determination.

\section{Different treatments levels}

\section{a. Control}

b. Salts level $3 \mathrm{dSm}^{-1}+$ Azolla

c. Salts level $7 \mathrm{dSm}^{-1}+$ Azolla

\section{Initial growth of rice}

In initial growth of rice study that how much azolla promoting rice plant initially in saline condition and how much can die.

\section{Plant height}

In each plot five Plants were selected and measure the length of each plant from top to bottom and taken average of five plants.

\section{Results and Discussion}

The experimental study conducted at National Agriculture Research Center Islamabad during june-2018.The following experimental parameter were study Electric Conductivity, pH, texture, initial growth, and Plant height.

\section{Electrical conductivity (EC)}

Specific electrical conductivity of a solution is directly related to its ion content. It is measured with a conductivity cell or EC meter and expressed in milliohms or milli-Siemens ( $\mathrm{mS}$ ) per $\mathrm{cm} \cdot 1 \mathrm{Mho}=1$ Siemens. The original EC of Soil is 1.3 and after induces salinity level create the EC became reach to $7 \mathrm{dSm}^{-1}$.

\section{pH}

When the $\mathrm{pH}$ meter calibration is done, rinse the electrode and place into the sample and wait for reading, the initial reading of soil sample is 7.6. The $\mathrm{pH}$ after the development of salinity reaches to 8.2 .

\section{Soil texture}

Texture refers to the size of the particles that make up the soil.The terms sand, silt, and clay refer to relative sizes of the soil particles.Sand, being the larger size of particles, feels gritty.Silt, being moderate in size, has a smooth or floury texture. Clay, being the smaller size of particles, feels sticky. After the analysis of soil 
sample by hydrometer the soil class become occurred in clay soil texture.

\section{Initial growth of rice}

In initial growth of rice studied, the data show that initial growth in control was to week as compare to treatment three. In treatment two where the salinity $3 \mathrm{dSm}^{-1}+$ Azolla were show no resistance to growth but in treatment three where the salinity $7 \mathrm{dSm}^{-1}+$ Azolla were show to much resistance.

\section{Plant height}

In each plot five Plants were selected and measure the length of each plant from top to bottom and taken average of five plants. The length of control pot rice is $40 \mathrm{~cm}$ mean without azolla and treatment two the average height of the plants was $70 \mathrm{~cm}$ where the salinity level is $3 \mathrm{dSm}-1+$ Azolla. In treatment three where the salinity $7 \mathrm{dSm}-1+$ Azolla show $43 \mathrm{~cm}$ plant height.

\section{Conclusion}

In this experiment we conclude that azolla can promote the rice growth up certain salinity level because azolla can reduce the soil EC and soil pH and also provide nitrogen.

\section{References}

1. Hove CV, Lejeune A (1996) Does Azolla has any future in agriculture? Biological Nitrogen Fixation Associated with Rice Production. p. 83-94.

2. Mian MH (2002) Azobiofer: a technology of production and use of Azolla as biofertiliser for irrigated rice and fish cultivation. In: Moore AW (Ed.), Azolla: biology and agronomic significance. Bot Rev 35: 1730.

3. Sarkar A, Jana S (1986) Heavy metal pollutant tolerance of Azolla pinnata. Water Air Soil Pollut 27(1-2): 15-18.

4. Shiomi N, Kitoh S (1987) Nutrient absorption capacity of Azolla from waste water and use of Azolla plant as biomass. J Plant Nutr 10(9-16): 1663-1670.
5. Kannaiyan S, Somporn C (1989) Effect of high temperature on growth, nitrogen fixation and chlorophyll content of five species of Azolla Anabaena symbiosis. Biol Fertil Soils 7(2): 168-172.

6. Moore (1969) Mosaic Units. Wiley Online. pp. 145-158.

7. Peoples MB, Herridge DF, Ladha JK (1995) Biological nitrogen fixation: an efficient source of nitrogen for sustainable agricultural production. Plant Soil 174(1-2): 3-28.

8. Singh AL, Singh PK (1990) Intercropping of Azolla biofertlizer with rice at different crop geometry. Trop Agric 67: 350-354.

9. Mian MH, Kashem MA (1995) Comparative efficiency of some selected methods of applying Azolla for cultivation of irrigated rice. Bangladesh J Crop Sci 6: 29-36.

10. Cisse M, Vlek PLG (2003) Influence of urea on biological N2 fixation and $N$ transfer from Azolla intercropped with rice. Plant Soil 250(1): $105-112$.

11. Kannaiyan S (1993) Nitrogen contribution by Azolla to rice crop. Proc Indian Natl Sci Acad Part B Biol Sci 59: 309-314.

12. Bray F (1986) The Rice Economies, Technology and Development in Asian Societies. Basil Blackwell. pp. 254.

13. Ahmad A Al-Noaim, Siddig H Hamad (2004) Effect of Bio-fertilization Along with Different Levels of Nitrogen Fertilizer Application on the Growth and Grain Yield of Hassawi Rice (Oryza sativa L.) Scientific Journal of King Faisal University 5(2): 1425.

14. Choudhury ATMA, Kennedy IR (2004) Prospects and potentials for systems of biological nitrogen fixation in sustainable rice production. Springer-Verlag 2004. Biol Fertil Soils 39: 219-227.

15. Kennedy IR, Choudhury ATMA (eds) Biofertilisers in action. Rural Industries Research and Development Corporation, Canberra. p. 4554.

16.ZNT, Heulin T, Hartmann A (1994) Biological nitrogen fixation associated with rice production. Kluwer Aacademic Publishers, Dordrecht. p. 83-94.

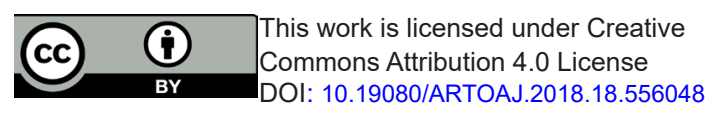

\section{Your next submission with Juniper Publishers will reach you the below assets}

- Quality Editorial service

- Swift Peer Review

- Reprints availability

- E-prints Service

- Manuscript Podcast for convenient understanding

- Global attainment for your research

- Manuscript accessibility in different formats

( Pdf, E-pub, Full Text, Audio)

- Unceasing customer service

Track the below URL for one-step submission https://juniperpublishers.com/online-submission.php 